\title{
Pablos de Segovia ilustrado por Luis García-Ochoa: un caso de retrato-robot
}

\author{
Emmanuel Marigno Vazquez \\ Université de Lyon / Saint Etienne \\ Campus de Saint Etienne \\ Faculté Arts, Lettres et Langues \\ 33, Rue du 11 Novembre \\ 42023 Saint Etienne Cedex 2 \\ Francia \\ emmanuel.marigno@univ-st-etienne.fr
}

[La Perinola, (Issn: 1138-6363), 22, 2018, pp. 177-188]

DOI: $10.15581 / 017.22 .177-188$

Sobre figuras quevedescas, se podría citar toda una literatura bibliófila ilustrada que arranca ya en el xvII, con reconocidos estampadores -Clowet en particular ${ }^{1}$, , que incluso por veces influyeron en el arte de la estampa hasta llegar a la centuria romanticista y a nuestro siglo XXI en que las estampas a obras satírico-burlescas de Quevedo no cesaron de ser editadas, como El Buscón, La Hora de todos, Los Sueños o demás poemas².

Entre esta magnífica galería de imágenes -aguafuerte, linograbado, litografía, xilografía, etc.- llama la atención el retrato de Pablos de Segovia inventado por Luis García-Ochoa. En efecto, no existe descripción física de Pablos en la novela picaresca ${ }^{3}$ de Quevedo, por supuesto, por tratarse de una focalización interna que nos brinda un panorama del mundo externo - economía, religión, sociedad-. ¿En qué se arraiga pues el retrato que nos proporciona García-Ochoa? ¿A qué se refiere? ¿Cuáles son las posibles interpretaciones ${ }^{4}$ ?

Mi problemática consistirá aquí en esta “disociación» ${ }^{5}$ entre la imagen iconográfica de Ochoa y la imagen escritural de Quevedo, tanto más paradójica en tanto que acaba funcionando de modo «complementario» en la relación Imagen / Texto. A partir de una guía de lectura que entronca un aparato teórico y crítico de tipo narratológico y semiótico principalmente, empezaré demostrando las paradójicas relaciones entre

1. Marigno, 2008.

2. Marigno, 2010 y 2017.

3. Sobre la pertenencia o no del Buscón al género picaresco, ver Tobar Quintanar, 2012.

4. Sobre hipotextos que pudieron alimentar la creación de Pablos, ver Cabo Aseguinolaza, 2009.

5. Van der Linden, 2008. 
la estrategia narrativa de Quevedo en El Buscón y el género del retrato tal y como lo practica Ochoa; en un segundo tiempo, veremos cómo esta representación postmoderna de Pablos puede ser considerada como una contemporaneización de la figura picaresca, como una especie de reescritura de la imagen retórica de Quevedo; por fin, intentaremos apreciar el grado de originalidad y el sentido de esta enigmática figura del pícaro en el contexto de los siglos xx y xxi.

\section{Del texto de Quevedo a la imagen de Осhoa}

Desde una perspectiva narratológica, la figura del pícaro quevedesco sigue la tradición de la matriz definida por el anónimo Lazarillo en que el protagonista se expresa en voz autodiegética e intradiegética ${ }^{6} \mathrm{y}$ con mirada retrospectiva. Por lo demás, Pablos le brinda al lector una representación interior, personal y singular acerca del contexto exterior. Dicho de otra forma, en ningún caso Pablos se describe a sí mismo físicamente, y la mimesis ${ }^{7}$ picaresca no le brinda al lector sino una pintura de tipo socio-cultural y colectiva, y no un retrato físico y personal, aunque, eso sí, la focalización sea de tipo interno.

Si no tenemos pues descripción directa del protagonista por sí mismo, tampoco la tenemos por parte de los antagonistas -el Licenciado Cabra por ejemplo- y aún menos en boca de los personajes secundarios que aquí no se expresan ni en modo directo ni en estilo indirecto. De esta forma, el lector no dispone del menor rasgo físico que le permita reconstituir lo que podría ser el retrato físico de Pablos. La picaresca es un anti-retrato por definición, en lo relativo al protagonista.

Por cierto, existen retratos ecfrásticos entre las imágenes escriturales de Quevedo, pero ninguna del protagonista, solo de los antagonistas y, en particular, el retrato del Licenciado Cabra, que viene definido en la imagen retórica quevedesca como

un clérigo cerbatana, largo sólo en el talle, una cabeza pequeña, los ojos avecindados en el cogote, que parecía que miraba por cuévanos, tan hundidos y oscuros que era buen sitio el suyo para tiendas de mercaderes; la nariz, de cuerpo de santo, comido el pico, entre Roma y Francia, porque se le había comido de unas búas de resfriado, que aún no fueron de vicio porque cuestan dinero; las barbas descoloridas de miedo de la boca vecina, que de pura hambre parecía que amenazaba a comérselas; los dientes, le faltaban no sé cuántos, y pienso que por holgazanes y vagamundos se los habían desterrado; el gaznate largo como de avestruz, con una nuez tan salida que parecía se iba a buscar de comer forzada de la necesidad; los brazos secos; las manos como un manojo de sarmientos cada una. Mirado de medio abajo parecía tenedor o compás, con dos piernas largas y flacas. Su andar muy espacioso; si se descomponía algo, le sonaban los huesos como tablillas de san Lázaro; la habla ética, la barba grande, que nunca se la cortaba por no

6. Genette, 1972.

7. Genette, 1969. 
gastar, y él decía que era tanto el asco que le daba ver la mano del barbero por su cara, que antes se dejaría matar que tal permitiese: cortábale los cabellos un muchacho de nosotros. Traía un bonete los días de sol ratonado con mil gateras y guarniciones de grasa; era de cosa que fue paño, con los fondos en caspa. La sotana, según decían algunos, era milagrosa, porque no se sabía de qué color era. Unos, viéndola tan sin pelo, la tenían por de cuero de rana; otros decían que era ilusión: desde cerca parecía negra y desde lejos entre azul. Llevábala sin ceñidor; no traía cuello ni puños. Parecía, con esto y los cabellos largos y la sotana y el bonetón, teatino lanudo. Cada zapato podía ser tumba de un filisteo. ¿Pues su aposento?, aun arañas no había en él. Conjuraba los ratones de miedo que no le royesen algunos mendrugos que guardaba. La cama tenía en el suelo, y dormía siempre de un lado por no gastar las sábanas. Al fin, él era archipobre y protomiseria ${ }^{8}$.

Si nos referimos ahora a la ilustración que hace Ochoa del Licenciado Cabra, nos percatamos de que, por cierto, determinados elementos del texto ya no están en la imagen como por ejemplo el cuerpo «cerbatana, largo sólo en el talle» que «medio abajo parecía tenedor o compás, con dos piernas largas y flacas», tampoco está el «zapato que podía ser tumba de un filisteo». Estas elipsis textuales en la imagen de Ochoa se explican sencillamente por el género del Retrato, es decir, que Ochoa decide concentrar toda la écfrasis quevedesca en el único rostro del personaje.

La estrategia del Retrato presupone también que Ochoa aparte todos los elementos contextuales del texto que participan de la figura del Licenciado Cabra, como son la presentación contextualizada del aposento donde caun arañas no había en él. Conjuraba los ratones de miedo que no le royesen algunos mendrugos que guardaba. La cama tenía en el suelo, y dormía siempre de un lado por no gastar las sábanas».

Tratándose de una imagen fija, el dinamismo de la écfrasis quevedesca desaparece, en concreto, los verbos de movimiento como «su andar muy espacioso», también el hecho de que «le sonaban los huesos como tablillas de San Lázaro», el «habla ética» y el «un muchacho de nosotros» que «cortábale los cabellos». Además de estos verbos de acción, son los propios recursos de la imagen retórica quevedesca que se esfuman en este grabado, como los «cuévanos» que pasan a ser «tiendas de mercaderes» o el (gaznate» que se vuelve de (avestruz»; en suma, se deshace la imagen ochoesca de las principales figuras de la metáfora satírica quevedesca como son la animalización, la cosificación o la personificación, estructuras poéticas que fundamentan el dinamismo de la imagen quevedesca conectando lexemas pertenecientes a categorías lexicológicas incompatibles en el lenguaje normativo ${ }^{9}$.

La figura del Licenciado Cabra en Ochoa lleva pues las características de la señalada “disociación» puesto que se aleja parcialmente el artista del palimpsesto, sin embargo, sigue funcionando la relación entre

8. Quevedo, Historia de la vida del buscón, ed. Fernández Mosquera y Madroñal Durán, pp. 303-304.

9. Schwartz, 1983. 
imagen y texto gracias a la co-presencia de signos compartidos entre la red semiótica textual y el sistema semiótico iconográfico. A partir de esta constatación podemos decir que la figura textual y la gráfica constituyen un icono-texto ${ }^{10}$ que le brinda al espectador-lector una figura de doble filo, es decir, la representación en pie, contextualizada y dinámica del texto de Quevedo por una parte, y el retrato estático y sicológico que pinta Ochoa por otra. Dicho de otra forma, no se aleja el grabado ochoesco de la metáfora quevedesca, sino que la completa de por dentro: el icono-texto bibliófilo nos brinda pues dos caras -una gráfica y otra iconográfica- de lo que al fin y al cabo acaba siendo una misma (imagen mental» ${ }^{11}$.

Precisemos que el modo de representación de la figura en Ochoa, no solo se debe a una estrategia personal del artista, sino que también se explica por la diferencia de medium, es decir, que las modalidades de la semiótica textual son distintas de la iconográfica, siendo la recepción textual de tipo lineal y progresivo, cuando los signos iconográficos se aprehenden más bien de modo simultáneo -lo cual no excluye un orden de lectura: líneas de fuerza, punto de fuga, colores, valores, planos, etc.-.

En el retrato de Ochoa (Fig. 0), el espectador-lector penetra en la imagen por el mismo lugar que en el texto,

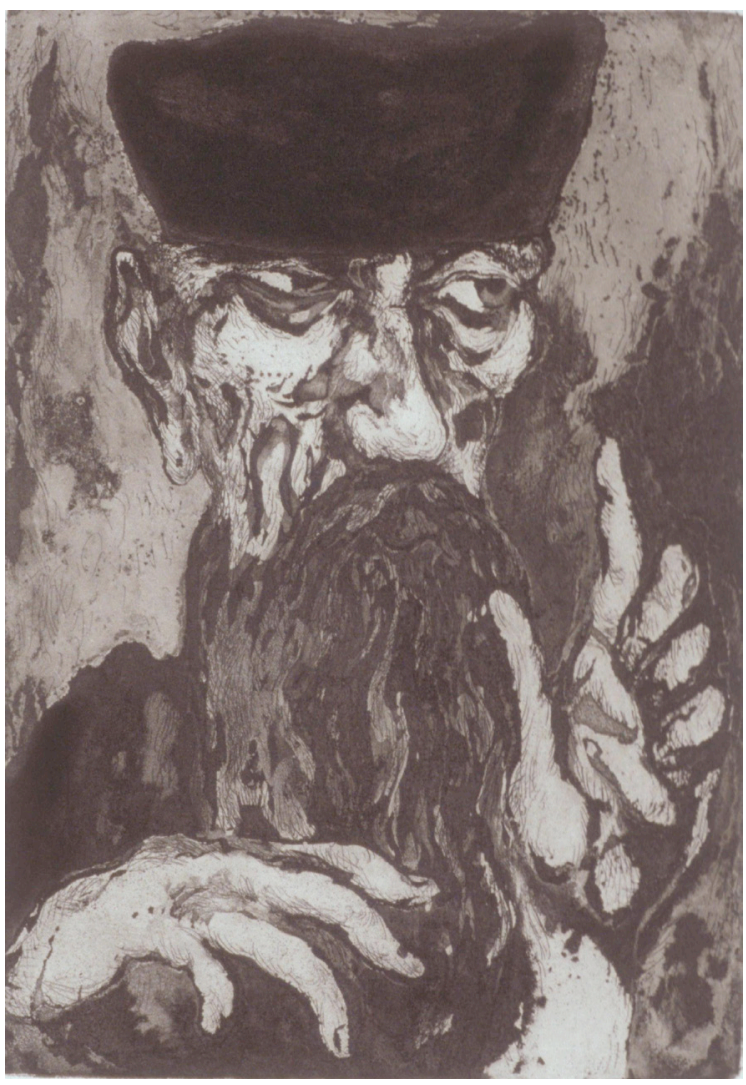

Fig. 0

Luis García-Ochoa, El pupilaje del Dómine Cabra, Aguafuerte, 320 x $240 \mathrm{~mm}$. Madrid, Casariego, 1979. 
o sea, por los ojos del Dómine Cabra, y encuentra en la figura ochoesca la misma «cabeza pequeña», idénticos “ojos avecindados en el cogote, que parecía que miraba por cuévanos, tan hundidos y oscuros que era buen sitio el suyo para tiendas de mercaderes; la nariz, de cuerpo de santo, comido el pico, entre Roma y Francia», las descuidadas «barbas descoloridas de miedo de la boca vecina, que de pura hambre parecía que amenazaba a comérselas», acabándose la lectura visual con «las manos como un manojo de sarmientos cada una». Por cierto, se le escapa al receptor el detalle de los dientes «que por holgazanes y vagamundos

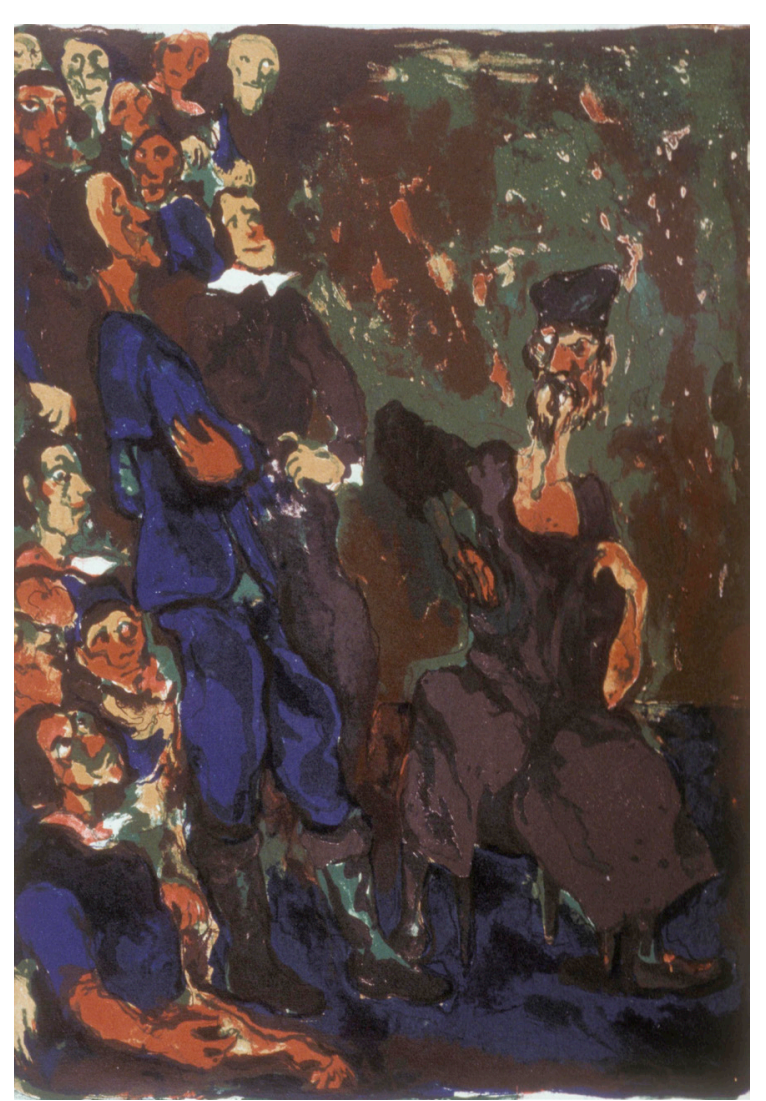

Fig. 1

Luis García-Ochoa, El pupilaje del Dómine Cabra, Litografía, 450 × $355 \mathrm{~mm}$. Madrid, Casariego, 1979. se los habían desterradom, aunque este punto no perturba de ningún modo el sentido del retrato grabado.

En definitiva, constatamos en este caso que la relación entre imagen y texto arranca de manera «disociada» -aunque parcialmente- para luego funcionar de modo “complementario» en la medida en que Ochoa elige centrarse en una presentación personal y sicológica mediante el género del Retrato, cuando Quevedo apunta a una pintura socio-cultural recurriendo a una écfrasis de tipo contextual. Ambas figuras, la de Ochoa y la de Quevedo, no pueden leerse como una suma sino bajo la modalidad de un diálogo entre se-

miótica textual e iconográfica.

La cuestión está ahora en el motivo de esta estrategia del artista. En efecto, la figura en aguafuerte del Dómine Cabra funciona como 
un prototipo en toda la versión ilustrada de Ochoa, es decir, que todas las representaciones siguen el mismo canon semiótico definido en este grabado, y esto, incluso cuando cambiamos de medium, o sea cuando pasamos de aguafuerte a litografía, de retrato en blanco y negro a representación en color. Dicho de otra forma, en todas las litografías (Fig. 1) el Dómine es reconocible por un mismo continuum de ojos, nariz, boca, barba, etc.

A la inversa, es imposible reconocer a Pablos en la masa de pícaros ilustrados por Ochoa. En efecto, si nos fijamos en la siguiente litografía (Fig. 2), protagonistas y figuras secundarias se entremezclan en un caos de idénticas líneas circulares que los encierran en un borbotón cromático de un camafeo azulado que lo uniformiza todo, en cuanto a los rostros, resulta difícil distinguir diferentes identidades entre personajes.

Si la figura del Dómine aparece como única, todas las litografías «con-funden» en una especie de figura común a todos los pícaros de la versión bibliófila, lo cual presupone que la figura del pícaro funciona como un tipo común cuyo interés no radica en el retrato físico o sicológico, sino en la función actancial dentro del esquema picaresco. La figura del pícaro deja de ser individual para volverse colectiva, no lleva estatuto singular sino función narrativa, diegética y mimetismo de tipo satírico-burlesco.

Respecto al texto de Quevedo, el espectador-lector entiende que las figuras litográficas no puedan figurar a Pablos individualmente, dado que la ausencia de imagen escritural

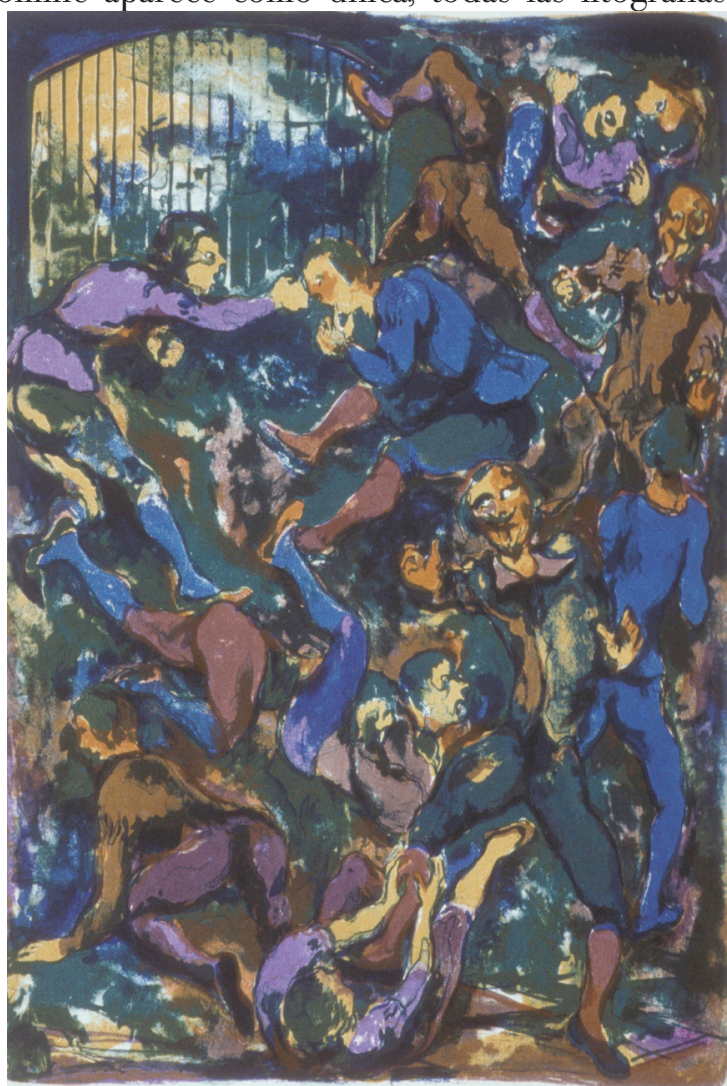

Fig. 2

Luis García-Ochoa, El pupilaje del Dómine Cabra, Litografía, 450 × $355 \mathrm{~mm}$. Madrid, Casariego, 1979. 
en el palimpsesto hace imposible una imagen iconográfica en la versión bibliófila de Ochoa.

$\mathrm{Y}$, sin embargo, el artista nos brinda un enigmático retrato de Pablos en forma de aguafuerte, verdadera figura misterio del que desconocemos el sustrato, por lo menos, en apariencia.

\section{La figura del Dómine: ¿Un RETRATO AL REvÉs?}

Acabamos de ver que, la única écfrasis más «cercana» a la figura de Pablos de la que dispone el espectador-lector, y el artista, es la del Dómine Cabra. Retomando el esquema de Propp ${ }^{12}$, no resulta descalabrado pensar que la figura del protagonista, Pablos (Fig. 3), podría deducirse de las características de la figura del antagonista, el Dómine Cabra, siguiendo la lógica actancial y el simbolismo de la semiótica textual e

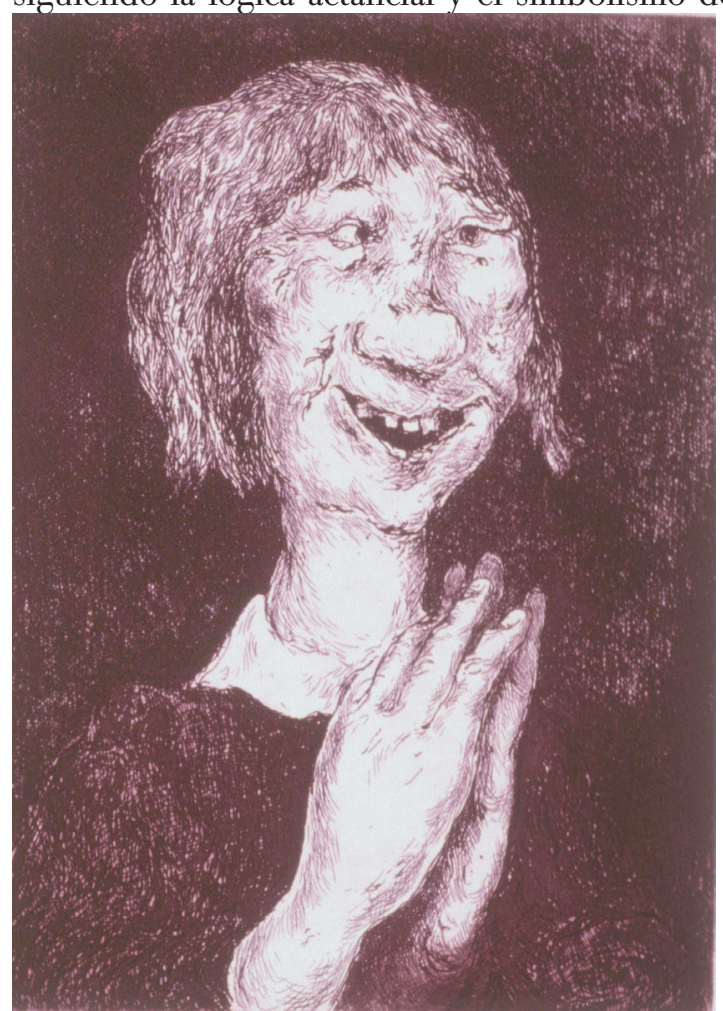

Fig. 3

Luis García-Ochoa, El pupilaje del Dómine Cabra, Aguafuerte, 290 x $245 \mathrm{~mm}$. Madrid, Casariego, 1979. iconográfica anteriormente señalada.

Compartidas manos, compartida boca y compartida nariz sin dientes parecen funcionar como signos semióticos que reúnen el retrato del Dómine Cabra -el ecfrástico de Quevedo y el iconográfico de Ochoay el retrato de Pablos. Además, una idéntica composición de aguafuertes nos presenta a dos figuras asomando de un fondo en negro -en el caso de Pablosy otro en camafeo de grises claro-oscuros en el Dómine Cabra-. Llama también la atención que ambas figuras aparecen con mirada igualmente dirigida hacia un fuera de campo en la parte derecha. Por fin, una luz frontal y anti-aca-

12. Propp, 1970. 
démica - ¿anti-héroes? - alumbra de igual modo el rostro de sendas figuras.

La composición análoga de ambas estampas, los compartidos signos semióticos, el recurso al mismo medium -aguafuerte-, nos conduce a pensar que Ochoa deduce el retrato físico de Pablos de una lectura invertida del retrato del Dómine Cabra, a su vez arraigado en el texto de Quevedo: Pablos viene retratado con pelo claro -irubio?- por ser sombrío el de Dómine Cabra, tiene rostro redondeado y rellenito al contrario del alargado y flaco del Dómine y lleva ojos pequeños que son lo contrario de los de Cabra. Las avarientas manos del Dómine se vuelven aquí manos alegres que quizá celebran acontecimientos burlescos, recordando así el «Dale aplauso que bien lo merece» del discutido “Prólogo al Lector»"13.

Acerca de las manos, Ochoa no hace sino poner de relieve una seña de identidad esencial para el personaje y para el género picaresco. La vida de Pablos es fruto de unas manos, las suyas propias -vive de robos- y las de su padre, quien declara:

- Hijo, esto de ser ladrón no es arte mecánica sino liberal.

Y de allí a un rato, habiendo suspirado, decía:

- De manos. Quien no hurta en el mundo no vive. ¿Por qué piensas que

los alguaciles y alcaldes nos aborrecen tanto ${ }^{14}$ ?

Y acerca del pelo supuestamente rubio, o por lo menos castaño muy claro en el aguafuerte de Ochoa, tenemos que subrayar semejante singularidad, pues, en la historia del arte, los pícaros suelen tener pelo oscuro, basta con citar el Joven mendigo de Bartolomé Esteban Murillo ${ }^{15}$ o los niños de la Vieja friendo huevos ${ }^{16}$ y El aguador de Sevilla ${ }^{17}$ de Diego Velázquez.

Dicho de otra forma, Ochoa deduce mediante una lógica gráfica lo que hubiera podido ser, según él, una posible écfrasis quevediana de la figura de Pablos. Las dos figuras, la del Dómine y la de Pablos, funcionan pues como un díptico invertido, en que lo austero y avariento del antagonista Dómine se convierte en risa y generosa alegría en el protagonista Pablos.

La lógica invertida, al fin y al cabo, es la que autodefine en el texto -aunque con meta satírico-burlesca por parte del autor- la identidad de Pablos, quien declara desde el íncipit ser cosa opuesta a lo que fueron sus padres. Del mismo modo, la figura de Pablos se opone también

13. Tobar Quintanar, 2011.

14. Quevedo, Historia de la vida del buscón, ed. Fernández Mosquera y Madroñal Durán, p. 298.

15. Murillo, Joven mendigo, óleo sobre lienzo, 1650, 137 x 115 cm, París, Louvre.

16. Velázquez, Vieja friendo huevos, óleo sobre lienzo, 1618, 100,5 x 119,5 cm, Edimburgo, Galería nacional de Escocia.

17. Velázquez, El aguador de Sevilla, óleo sobre lienzo, 1620, 106,7 x 81 cm, Londres, Hapsley House. 
a la del Dómine Cabra, que sustituye a la madre y al padre, con lo cual, la estrategia del díptico invertido de Ochoa sigue la pura lógica textual:

Hubo grandes diferencias entre mis padres sobre a quién había de imitar en el oficio; mas yo, que siempre tuve pensamientos de caballero desde chiquito, nunca me apliqué ni a uno ni a otro ${ }^{18}$.

Ochoa crea pues el retrato físico de Pablos -ausente en Quevedo- a partir de su recepción de la écfrasis textual, función exotópica de recreación que Ricoeur ${ }^{19}$ llama «triple mímesis». Este tipo de recepción en Ochoa permite que la ilustración «complete» el palimpsesto proporcionándole al espectador-lector una imagen que, potencialmente, figura en el texto pero de manera implícita y connotativa. Conviene insistir en lo singular de esta relación entre imagen y texto, en particular, si nos referimos a la teoría de Barthes $^{20}$, según la cual la semiótica textual sería de tipo denotativo y explícito, cuando la iconográfica sería de raigambre connotativa e inductiva. El caso singular del retrato físico de Pablos por Ochoa demuestra que una relación imagen / texto invertida también existe, y que lo «no-dicho» del texto puede inducir una forma de complementariedad en el receptor, siempre que se respete una lógica textual. El retrato litográfico de Pablos se aparenta a una alegoría iconográfica, o sea que se hace visible la parte invisible del texto.

El caso de la figura de Pablos es original respecto al Buscón de Quevedo, pero existe por lo menos otro ejemplo en el ámbito de la ilustración bibliófila. En efecto, Orlando Pelayo consigue semejante proeza, o sea pintar lo desconocido, en su versión de Lazarillo de Tormes. El artista asturiano consigue brindarle al espectador-lector un retrato ya no del personaje Lázaro, lo cual tendría algún arraigo textual por lo menos, sino un retrato figurativo del propio autor supuestamente anónimo. En el caso de Pelayo, la reconstitución de la figura autoral es mucho más misteriosa y difícil de entender en tanto que no se puede saber cuál es el punto de partida del artista, no siendo ni el texto ni cualquier otro elemento contextual o paratextual. Notemos sin embargo, que dicha representación de Pelayo no supera tanto lo anónimo del autor, por llevar la figura del aguafuerte máscara ante los ojos y barba abundante -si es que el aludido autor del Lazarillo la llevase-. Y en lo que se refiere a la figura de Lázaro en las ilustraciones, el estilo de «figuración abstracta» típica de Pelayo hace que el protagonista no sea reconocible (Fig. 4).

El ejemplo extremo y no menos interesante de Pelayo, aunque difícil de interpretar, demuestra que la figura de Pablos en Ochoa es digna de análisis y credibilidad, por lo menos como experimentación plástica y textual, en tanto que intento coherente tanto desde una perspectiva

18. Quevedo, Historia de la vida del buscón, ed. Fernández Mosquera y Madroñal Durán p. 298.

19. Ricoeur, 1983.

20. Barthes, 1964. 


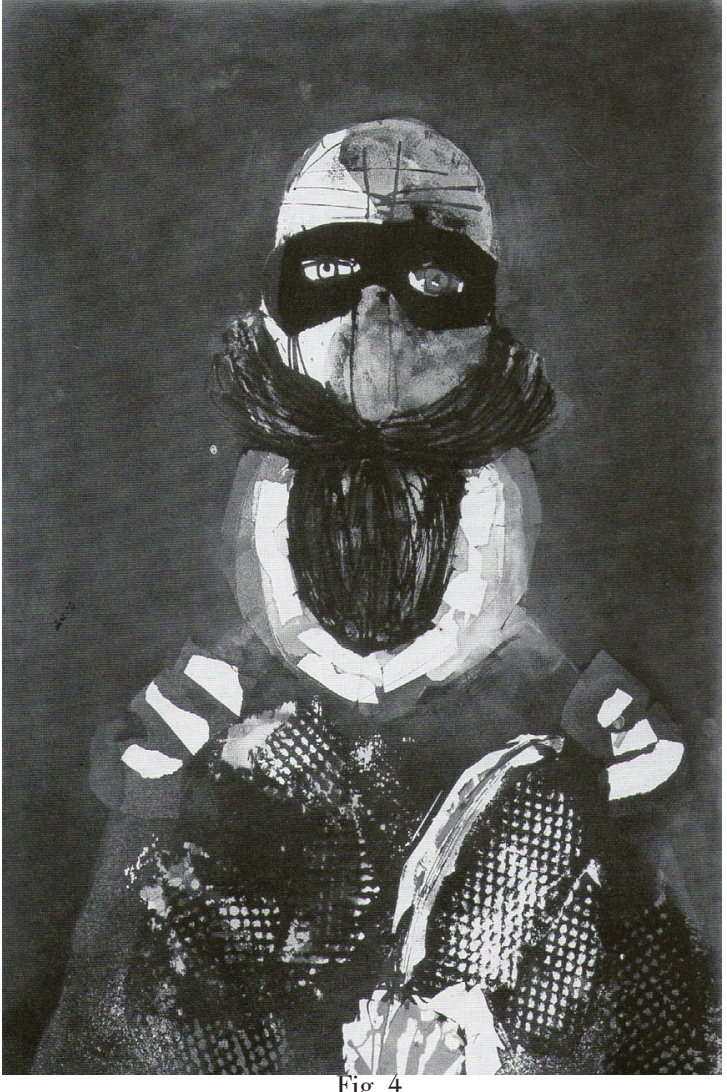

Orlando Pelayo,

La vida de Lazarillo de Tormes y de sus fortunas y adversidades, Aguafuerte, 505 x 385 mm.

Madrid, Casariego, 1975. de semiótica iconográfica como textual. Por otra parte, donde Pelayo intenta retratar la sicología de los autores cuyas obras ilustra mediante el género del Retrato, Ochoa se dedica a los personajes de ficción. Por lo visto, Pelayo accede al retrato del personaje mediante la figura autoral, cuando Ochoa lo consigue deconstruyendo / reconstruyendo el propio texto, involucrando a protagonistas y esquemas narrativos, o sea, el conocido «polifonismo» de Bakhtine ${ }^{21}$. El propio Pelayo declara trabajar menos sobre el texto que sobre una técnica que compara al «retrato robot», en que el artista suma toda una serie de datos acerca del autor para constituir un retrato esquemático del autor:

A quien como yo se propone grabar para este «Polifemo» un retrato de Góngora, se le ofrece en principio dos posibilidades: inspirarse y ampararse en el de Velázquez o bien hacerlo al dictado de los testimonios literarios, construyendo algo parecido a lo que hoy se llama retrato robot, con lo que esto conlleva de segura inexactitud aunque también de divertido juego ${ }^{22}$.

La lectura de la imagen retórica de Quevedo, comparada con la iconográfica de Ochoa y la autoral de Pelayo, anclan la propuesta de retrato que nos brinda Ochoa acerca del desconocido Pablos como un caso

21. Bakhtine, 1978.

22. Pelayo, en VV. AA., 1992, p. 23. 
singular de reconstitución artística, y prácticamente científica, de un desconocido protagonista picaresco: Pablos de Segovia.

\section{Conclusiones}

Quevedo, en su Vida del Buscón, trata el personaje como función simbólica y con una hermenéutica de corte sociocultural y socioeconómico. Ochoa, al contrario, considera el personaje como finalidad de por sí: el retrato deja de ser colectivo para volverse individual.

La técnica de Ochoa parte de una investigación acerca de la imagen escritural del Dómine Cabra, a la que añade la lógica actancial que vertebra la novela de Quevedo. El artista establece además una dialéctica plástica entre el medium litográfico, que le permite un retrato de tipo colectivo, y el aguafuerte que funciona como lenguaje privilegiado del retrato individual.

De este modo, Ochoa retoma el retrato colectivo que nos proporciona Quevedo gracias a los recursos del género picaresco, a la vez que supera el artista los límites que impone esta narrativa autodiegética que hace imposible el autorretrato físico -focalización interna-.

Por fin, este retrato único y original de Pablos, quizá responda a una forma de recepción moderna del protagonista, una forma de interrogante y planteamiento visual contemporáneo que por lo visto no tenía lugar en tiempos de Quevedo.

\section{BibLiografía}

Arellano, Ignacio y Canavaggio, Jean, Rostros y máscaras: personajes y temas de Quevedo, Pamplona, Eunsa, 1999.

Bakhtine, Mikhail, Esthétique et théorie du roman, Paris, Gallimard, 1978.

Barthes, Roland, «Rhétorique de l'image», en Communications, 4, 1, pp. 40-51.

Béguin-Verbrugge, Annette, Images en texte, Images du texte. Dispositifs graphiques et communication écrite, Villeneuve d'Ascq, Presses universitaires du Septentrion, coll. Information-communication, 2006.

Belting, Hans, Pour une anthropologie des images [1984], Paris, Gallimard, 2004.

Cabo Aseguinolaza, Fernando, «El Buscón a la luz de los Quijotes», La Perinola, 13, 2009, pp. 229-248.

García-Ochoa, Luis, El pupilaje del Dómine Cabra, Madrid, Casariego, 1979.

Gargano, Antonio, “La novela picaresca entre realismo y representación de la realidad: el caso del Buscóns, La Perinola, 10, 2016, pp. 123-131.

Genette, Gérard, Figures II, Paris, Éditions du Seuil, 1969.

Genette, Gérard, Figures III, Paris, Éditions du Seuil, 1972.

Jauralde Pou, Pablo, «Encomiendas ideológicas al Buscón», La Perinola, 2, 1998, pp. 87-103.

Klinkenberg, Jean-Marie, «La relation texte-image. Essai de grammaire générale», en Bulletin de la Classe des Lettres, 6 /XIX, 2008, pp. 21-79 [http://gemca.fltr.ucl. ac.be/docs/cahiers/20090128_Klinkenberg.pdf, Consultado 18/04/2017].

Kundera, Milan, L'Art du roman, Paris, Gallimard, 1986.

Louvel, Liliane, Texte / Image. Images à lire, textes à voir, Rennes, Pur, 2002. 
Marigno, Emmanuel, «Les Sueños de Quevedo et le Sueño de Goya: du texte des Sueños et de ses illustrations par Clowet, à la planche 43 de Goya», en Antoine Fraile (dir.), Les arts dans le monde hispanique, Angers, Presses Universitaires d'Angers, 2008, pp. 61-68.

Marigno, Emmanuel, L'écriture satirique de Quevedo illustrée aux $X X^{e}-X X I^{e}$ siècles, Lille, Septentrion, 2010.

Marigno, Emmanuel, «Las ilustraciones de Amabel Míguez de la Sierra (2011) a las Jácaras de Quevedom, Hipogrifo, 4, 3, 2017 (en prensa).

Marsh, Emily E. y Marilyn Domas White, "A Taxonomy of Relationships between Images and Text: Additional Examples Illustrating its Application», Journal of Documentation, 647, 2003, pp. 647-672.

Martinec, Radan y Andrew Salway, «A System for Image-Text Relations in New (and Old) Media», Visual Communication, 3, 4, 2009, pp. 337-371.

Orlando Pelayo, La vida de Lazarillo de Tormes y de sus fortunas y adversidades, Madrid, Casariego, 1975.

Propp, Vladimir, Morphologie du conte, Paris, Seuil, 1970.

Quevedo, Francisco de, Historia de la vida del buscón, ed. Santiago Fernández Mosquera y Abraham Madroñal Durán, Madrid, Fundación José Antonio de Castro, 2012.

Quevedo, Francisco de, Vida del Buscón, ed. Alfonso Rey, Santander, Biblioteca Menéndez Pelayo, 2005.

Quevedo, Francisco de, Vida del Buscón, ed. Edmond Cros, Barcelona, Penguin Clásicos, 2015.

Quevedo, Francisco de, Vida del Buscón, ed. Milagros Rodríguez Cáceres, Barcelona, Octaedro, 2001.

Quevedo, Francisco de, Vida del Buscón, ed. Víctor Roncero, Madrid, Biblioteca Nueva, 1999.

Ricœur, Paul, Temps et récit I. Lintrigue et le récit historique, Paris, Seuil, 1983.

Roncero López, Víctor, «El humor, la risa y la humillación social: el caso del Buscóns, La Perinola, 10, 2016, pp. 271-286.

Schwartz-Lerner, Lía, Metáfora y sátira en la obra de Quevedo, Madrid, Taurus, 1983.

Schwartz-Lerner, Lía, «La identidad genérica del Buscón. Notas sobre la trayectoria de su recepción», La Perinola, 14, 2010, pp. 19-32.

Tobar Quintanar, María José, «El decoro cómico del Buscón: parodia de la Atalaya de Mateo Alemán», La Perinola, 16, 2012, pp. 259-279.

Tobar Quintanar, María José, “La autoría quevediana del prólogo "Al Lector" del Buscón», La Perinola, 15, 2011, pp. 333-345.

Van der Linden, Sophie, “L'album, le texte et l'image», en Le Français aujourd'hui, 161/2, 2008, pp. 51-58 [https://www.cairn.info/load_pdf. php?ID_ARTICLE=LFA_161_0051, Consultado 18/04/2017].

vv.AA., Orlando Pelayo. Pintura y obra gráfica, Oviedo, Palacio Revillagigedo / Caja de Ahorros de Asturias, 1992. 